\title{
INFLUENCE OF CLIMATE CHANGES ON HEALTH (REVIEW)
}

\author{
Nada Pop-Jordanova1, Evgenija Grigorova ${ }^{2}$ \\ ${ }^{1}$ Macedonian Academy of Sciences and Arts, R. Macedonia \\ ${ }^{2} \mathrm{PhD}$ student Public Health, Medical Faculty, Skopje, R. Macedonia \\ Corresponding Author: popjordanova.nadica@gmail.com
}

\begin{abstract}
Although climate changes are one of the most serious public health risks for all nations, it appears that the medical society in the East European countries is not too much concerned.

The aim of this paper is to point out the main treats on health provoked by climate changes.

The literature review was the source of information. Based on the PubMed where in 2015 more than 65,000 papers were dedicated to different aspects of the influence of the climate changes on the human health, as well as 3,500 articles for the pediatric population, we present a review of the main health risks. Especially, the impact of the climate changes on the children's health is overviewed.

In separate parts, the thermal stress, extreme weather events, changes of infection's pattern, how to measure health risks as well as some mitigation measures are discussed.
\end{abstract}

Key words: climate changes, health risks, review

\section{Introduction}

Although climate changes are one of the most serious public health risks for all nations, it appears that the medical society in the East European countries is not too much concerned.

It is proven that climate changes affect mainly the social and environmental determinants of health - clean air, safe drinking water, sufficient food and secure shelter. Children, the elderly, and communities living in poverty are among the most vulnerable [1].

It is supposed that the global climate has been affected especially over the last 50 years by human activities - particularly the burning of fossil fuels. In this processes, sufficient quantities of carbon dioxide and other greenhouse gases are released and provoke additional heat in the lower atmosphere. It is calculated that in the last 130 years, the world has warmed by approximately $0.85^{\circ} \mathrm{C}$. Each of the last three decades has been successively warmer than any preceding decade. Sea levels are rising, glaciers are melting and precipitation patterns are chan- ging. Extreme weather events are becoming more intense and frequent.

It is expected that between 2030 and 2050, climate changes will cause approximately 250.000 additional deaths per year, from malnutrition, malaria, diarrhoea and heat stress.

The direct damage costs to the health (i.e. excluding costs in health-determining sectors such as agriculture and water and sanitation), are estimated to be between US\$ 2-4 billion/year by 2030 [2, 3, 4, 5].

The aim of this paper is to point out the main treats on health provoked by climate changes. Especially, the health problems related to the climate changes in childhood will be discussed.

\section{Methodology}

The literature review was the source of information. Only on the PubMed in 2015 it can be found more than 65.000 papers dedicated to different aspects of the influence of the climate changes on human health. For the pe- 
diatric population, the number of articles is about 3.500 only for 2015 . It is obvious that this problem is very actual and raises many questions. The main results from different publications will be presented in selected parts.

\section{Thermal stress}

Extreme high air temperatures are dangerous particularly for elderly people and young children. In the heat wave of the summer of 2003 in Europe, for example, more than 70,000 excess deaths were recorded. High temperatures also raise the levels of ozone and other pollutants in the air that exacerbate cardiovascular and respiratory disease [6].

Ozone smog forms when pollution from vehicles, factories, and other sources reacts with sunlight and heat. Increasing temperatures accelerate this process and result in more smog. Smog - composed of ground-level ozone, sulfur dioxide, nitrogen dioxides and carbon monoxide - is not only rich in greenhouse gases, but also in chemicals that put people at risk of premature death, aggravate asthma and trigger other respiratory and cardiovascular diseases. In the U.S., for instance, approximately 44 percent of the Americans live in regions where air pollution levels are too dangerous to breathe, according to the American Lung Association [7]. Added to other allergens in the air, smog influences the carbon dioxide levels causing plants to produce more pollen. Also, as dry areas get dryer, wildfire risks go up and smoke from burning landscapes intensifies poor air quality [8-12].

One specific feature of the climate changes is the increasing heat exposure in many workplaces where efficient cooling systems cannot be applied. Excessive heat exposure is a particular problem for working people because of the internal heat production when muscle work is carried out. The physiological basis for severe heat stroke, other clinical effects, and heat exhaustion is well known $[13,14,15]$.

There is an additional impact of the climate changes to the concentration of persistent organic pollutants particles (POPs). POPs are composed mainly of polychlorinated dibenzop-dioxins and dibenzofurans (PCDD/Fs), polychlorinated biphenyls (PCBs) and pesticides $[16,17,18]$. In our country, a few years ago the measurement of POPs became regular and this autumn a very high level of POPs were registered, which are dangerous for the human health. The most exposed towns for POPs were Skopje (the capital) and Tetovo where the concentration of POPs was 10 time higher than normal. People were alarmed not to go on the streets and to stay at home, especially people with chronic cardiovascular disease and asthma.

As temperatures rise and precipitation decreases, water quality can be also jeopardized. Shrinking amounts of water can concentrate contaminants such as heavy metals, industrial chemicals and pesticides, and sediments and salts. During droughts, drinking water supplies are susceptible to harmful algal blooms and other microorganisms. As we said before, pollen and other aeroallergen levels are also higher in extreme heat. These can trigger asthma, which affects around 300 million people [19, 20].

In addition, rising temperatures and variable precipitation decrease the production of staple foods in many of the poorest regions. This will increase the prevalence of malnutrition and undernutrition, which currently cause 3.1 million deaths every year [21].

\section{Extreme weather events}

It is estimated that every year, disasters related to weather events result in over 60,000 deaths, mainly in developing countries. The rising sea levels and the increasingly extreme weather events will destroy homes, medical facilities and other essential services in many countries. Scientists project that climate changes will increase the frequency of heavy rainstorms, putting many communities at risk for devastation from floods.

As an example, we remember Hurricane Mitch in 1998, when there were six feet of rain in Central America in three days. In its wake, the incidence of malaria, dengue fever, cholera, and leptospirosis soared. In 2000, rain and three cyclones inundated Mozambique for six weeks, and the incidence of malaria rose fivefold. The Hurricane Katrina came afterword, gathering steam from the heated Gulf of Mexico and causing devastation in the coastal communities [19].

Additionally, the increasingly variable rainfall patterns affect the supply of fresh wa- 
ter. A lack of safe water can compromise hygiene and increase the risk of diarrhoeal disease, which kills approximately 760,000 children aged under 5, every year. The extreme precipitation is expected to continue to increase during the current century. Floods contaminate freshwater supplies, heighten the risk of waterborne diseases, and create breeding grounds for disease-carrying insects such as mosquitoes. They also cause drownings and physical injuries, damage homes and disrupt the supply of medical and health services and increase the possibilities for conflicts [22].

Generally, in 2014, losses from weather and climate disaster events reached trillions of US\$. Between 1994 and 2013, more than 530,000 people died worldwide as a direct result of over 15,000 extreme weather events. The year of 2015 ranks as the warmest ever recorded while the 10 warmest years on a 134year record have all occurred since 2000 . There are already people being officially called "climate refugees," and the conflicts exacerbated by climate changes and extreme weather events are on the rise [23].

\section{Patterns of infection}

Climatic conditions strongly affect waterborne diseases and diseases transmitted through insects, snails or other cold blooded animals. They result in longer transmission seasons of the important vector-borne diseases and alteration of their geographic range. For example, climate change is projected to widen significantly the area of China where the snailborne disease schistosomiasis occurs [24]. The same is true on a global scale: increases in heat, precipitation, and humidity can allow tropical and subtropical insects to move from regions where infectious diseases thrive into new places.

Malaria is strongly influenced by climate. Transmitted by Anopheles mosquitoes, malaria kills almost 600.000 people every year - mainly African children under 5 years. In the period after World War II malaria was eradicated in our country. But some cases have been diagnosed again this summer related to the rising mosquitos number as well as the climate changes.

The Aedes mosquito vector of dengue fever is also highly sensitive to climate conditions. Between 1995 and 2005 it is reported that nearly 4,000 cases of imported and locallytransmitted Dengue Fever were registries in the U.S., and that number rises to 10,000 when the cases at the Texas-Mexico border region are included. Dengue Fever, also known as "Breakbone Fever", is characterized by high fever, headaches, bone and joint aches, and a rash. Recurrent infection can lead to bleeding, seizures, and death.

Lyme disease - transmitted primarily through bites from certain tick species - could expand throughout the United States and northward into Canada, as temperatures increase, allowing ticks to move into new regions. Rare cases of Lyme disease were suspected in our country too.

The West Nile virus, which first entered the U.S. in 1999, expanded rapidly westward across the country. By 2005 , over 16,000 cases had been reported. Warmer temperatures, heavy rainfall and high humidity have reportedly increased the rate of human infection [25-31].

As mentioned before, practically all these diseases are incidentally registered in our country and in the neighborhood too. For the purpose ofhealth improvement, infection control and disease management, the use of different types of Probiotics or the use of food containing Probiotics was recently suggested [32].

\section{Measuring the health effects from the climate changes}

Measuring the health effects from the climate changes can only be very approximate. Nevertheless, a WHO assessment concluded that climate change is expected to cause approximately 250,000 additional deaths per year between 2030 and 2050; 38,000 due to heat exposure in elderly people, 48,000 due to diarrhoea, 60,000 due to malaria, and 95,000 due to childhood undernutrition. These expectations must alert health workers $[3,33]$. In Table 1. are summarized the Health risks from the climate changes.

In addition to the infections, the climate changes influence the general mental health, including stress-related disorders, attention deficit, and diminution of the cognitive abilities, as well as the emotional expression. In this context, living in urban environment, without green spaces is worsening the global health. 
The most recent work measuring the differrenrtial affective responses to natural versus urban environments has employed Electroencephalography (EEG) and EEG-based emotional recognition software to measure changes in emotions while navigating city environments on foot. It was found that pedestrians that were walking on a busy urban shopping street and then entered a greenspace experienced reductions in arousal (long-term excitement) and frustration [34].

Table 1

Summary of health risks related to climate changes

\begin{tabular}{|l|l|l|}
\hline \multicolumn{1}{|c|}{ Climatic Event } & \multicolumn{1}{|c|}{ Intermediary } & \multicolumn{1}{c|}{ Health Outcome } \\
\hline Heat waves & $\begin{array}{l}\text { Increased ground-level } \\
\text { ozone, pollen }\end{array}$ & $\begin{array}{l}\text { Heat stress, stroke } \\
\text { Respiratory disease } \\
\text { exacerbation }\end{array}$ \\
\hline Increased mean temperature & $\begin{array}{l}\text { More hospitable to disease } \\
\text { vectors (e.g., mosquito, } \\
\text { ticks) } \\
\text { More hospitable to } \\
\text { infectious disease agents } \\
\text { (e.g., bacteria) }\end{array}$ & $\begin{array}{l}\text { Vector-borne diseases (e.g., } \\
\text { Lyme, malaria, dengue) }\end{array}$ \\
\hline Ozone depletion & UV radiation & fisease (e.g., cholera) \\
\hline Drought & $\begin{array}{l}\text { Water/food shortage } \\
\text { Lack of water safety }\end{array}$ & $\begin{array}{l}\text { Skin and eye maladies } \\
\text { Water-borne disease }\end{array}$ \\
\hline $\begin{array}{l}\text { Extreme weather event (e.g., } \\
\text { flooding, tornado, hurricane) }\end{array}$ & $\begin{array}{l}\text { Population movement } \\
\text { Lack of food/water safety }\end{array}$ & $\begin{array}{l}\text { Injuries, drowning } \\
\text { Conflicts }\end{array}$ \\
\hline Sea-level rise & Population movement & $\begin{array}{l}\text { Water-borne disease, } \\
\text { malnutrition }\end{array}$ \\
\hline Climate change generally & Stress & $\begin{array}{l}\text { Injuries, drowning } \\
\text { Conflicts } \\
\text { Dehydration, malnutrition }\end{array}$ \\
\hline
\end{tabular}

\section{Who is at risk?}

Climate changes can affect all the population, but some are more vulnerable than others. People living in small island developing states and other coastal regions, megacities, and mountainous and polar regions are particularly vulnerable. The most vulnerable population, as we said before, are children and elderly people.

\section{Climate change and children's health}

The effects of the climate changes on children's health include: physical and psychological sequelae of the weather disasters; increased heat stress; decreased air quality; altered disease patterns of some climate-sensitive infections; and food, water, and nutrient insecurity in vulnerable regions. The social foundations of children's mental and physical health are threatened by the spectre of far-reaching effects of unchecked climate changes, including community and global instability, mass migrations, and increased conflict. Pediatricians have a uniquely valuable role to play in the societal response to this global challenge.

Children's Environmental Health, the branch of pediatrics that studies the influence of the environment on children's health, becomes an increasingly visible and important component of the pediatric medicine. It arose in the 
second half of the 20th century through a melding of insights from the pediatric toxicology, nutritional epidemiology and social science research. Convergent research in these three fields has documented children's unique sensitivities to chemical, nutritional and psychosocial hazards during "windows of vulnerability" in early development and has showed that early-life exposures can produce disease and disability in childhood and across the lifespan.

Exposure to heat, air pollution, and radiation are often enhanced in urban areas, specifically under the current design of the majority of outdoor child play places. Such environmental exposures relate strongly to the behavior, activity, asthma, obesity, and overall child well-being. Current research indicates that a changing climate, growing urban population, and unsustainable design are projected to pose increasing complications.

Since the exposure to green spaces can restore attention, it may be able to ameliorate behavioral disorders exacerbated by mental fatigue. One such disorder is attention deficit hyperactivity disorder (ADHD), the most common behavioral disorder among children worldwide. The symptoms of the ADHD overlap with the symptoms of the mental fatigue (e.g., distractibility, irritability) caused by sustained and depleted directed attention. In some research it was found that green outdoor activity had a significantly greater effect than urban outdoor and indoor activities in reducing the ADHD symptoms $[35,36]$.

The contemporary ecological models of health prominently feature the natural environment as fundamental to the ecosystem services that support human life, health, and well-being. The natural environment encompasses and permeates all other spheres of influence on health. In this context, green buildings aim to improve human health through the design of healthy indoor environments [37, 38, 39]. In this context a few years ago in Macedonia was established a "Day of forest: Create a Climate Smart Future", when hundreds of people, students, schoolers and others voluntary are engaged to plant trees in the free places in the town as well as in the neighbourhood of the towns.

We showed that extreme events, both natural and anthropogenic, increasingly affect ci- ties in terms of economic losses and impacts on health and well-being. Urbanization, climate change and other geophysical and social forces interact with the urban systems in ways that give rise to the complex and in many cases synergistic relationships. Such effects may be mediated by location, scale, density, or connectivity, and also involve feedbacks and cascading outcomes

In 2015, the WHO Executive Board endorsed a new work plan on climate change and health. This includes:

- Partnerships: to coordinate with partner agencies within the UN system, and ensure that health is properly represented in the climate change agenda.

- Awareness raising: to provide and disseminate information on the threats that climate changes present to human health, and opportunities to promote health while cutting carbon emissions.

- Science and evidence: to coordinate reviews of the scientific evidence on the links between climate change and health, and develop a global research agenda.

- Support for implementation of the public health response to climate change: to assist countries to build capacity to reduce health vulnerability to climate change, and promote health while reducing carbon emissions.

\section{Summary}

It is now widely accepted that climate changes are occurring as a result of the accumulation of greenhouse gases in the atmosphere arising from the combustion of fossil fuels.

Climate change may affect health through a range of pathways, for example as a result of the increased frequency and intensity of heat waves, reduction in cold related deaths, increased floods and droughts, changes in the distribution of the vector-borne diseases and the effects on the risk of disasters and malnutrition.

The adaptation to the climate changes requires public health strategies and improved surveillance. The mitigation of the climate changes by reducing the use of fossil fuels and increasing the number of uses of the renewable energy technologies should improve health in the near-term by reducing exposure to air pollution. 


\section{REFERENCES}

1. Phua KL Redesigning healthcare systems to meet the health challenges associated with climate change in the twenty-first century. Journal of Emergency Management. 2015, 13(3): 255-263.

2. IPCC. Summary for Policymakers. In: Edenhofer O, R. Pichs-Madruga, Y. Sokona, E. Farahani, S. Kadner, K. Seyboth, A. Adler, et al. Minx editors. Climate Change 2014, Mitigation of Climate Change Contribution of Working Group III to the Fifth Assessment Report of the Intergovernmental Panel on Climate Change. Cambridge, United Kingdom and New York, NY, USA.: Cambridge University Press; 2014.

3. WHO. Quantitative risk assessment of the effects of climate change on selected causes of death, 2030s and 2050s. Geneva: World Health Organization, 2014.

4. McMichael A., Woodruff R, Hales S. Climate change and human health: present and future risks. The Lancet, Volume 367, No. 9513, p. 859-869, 11 March 2006.

5. Epstein P. Climate Change and Human Health. N Engl J Med 2005, 353: 1433-1436.

6. Robine JM, Cheung SL, Le Roy S, Van Oyen H, Griffiths C, Michel JP, et al. Death toll exceeded 70,000 in Europe during the summer of 2003. C R Biol. 2008, 331(2): 171-8.

7. De Blois J, Kjellstrom T, Agewall S, Ezekovitz JA, Amstrong PW, Atar D. The effects of Climate Change on Cardiac Health, Cardiology, 2015, 131 (4): 209-217.

8. Patz J, Campbell-Lendrum D, Holloway T, Foley J. Impact of regional climate change on human health. Nature, 438: 310-317.

9. Martens WJM Climate change, thermal stress and mortality changes, Social Science \& Medicine, 1998, 46 (3): 331-344.

10. Tait PW, Hanna EG A Conceptual Framework for Planning Systemic Human Adaptation to Global Warming. International Journal of Environmental Research and Public Health, 2015, 12 (9): 1070010722.

11. Huynen MM, Martens P Climate Change Effects on Heat- and Cold-Related Mortality in the Netherlands: A Scenario-Based Integrated Environmental Health Impact Assessment. International Journal of Environmental Research and Public Health. 2015, 12 (10), 13295-13320.

12. Bell M, Goldberg R, Hogrefe C, Patrick L, Kinney P, Knowlton K, Lynn B, Rosenthal J, Rosenzweig C, Parz J. Climnate change, ambient ozone, and health in 50 US cities, Climate change, 2007, 82 (1): 61-76.

13. Kjellstrom T. Imact of Climate Conditions on Occupational Health and Related Economic Losses: A New feature of global and urban health in the context of climate change. Asia-Pacific Journal of Public Health/ Asia-Pacific Academic Consortium for Public Health, 2015.
14. Raab KK. Health implication of a changing climate. Minnesota Medicine, 2015, 98 (5): 41-43.

15. Haines A, Kovats RS, Campbell-Lendrum D, Corvakan C. Climate change and human health: Impacts, vulnerability and public health, Public Health, 2006, 120 (7): 585-596.

16. Nadal M, Marques M, Mari M, Domingo JL. Climate change and environmental concentrations of POPs: A review. Environmental Research, 2015, 143 (Pt A): 177-185.

17. Takaro TK, Henderson SB. Climate change primer for respirologists. Canadian Respiratory Journal: Journal of Canadian Thoracic Society, 2015, 22 (1): 52-54.

18. Notas G, Bariotakis M, Kalogrias V, Andrianaki M. et al. Accurate prediction of severe allergic reactions by a small set of environmental parameters (NDVI, temperature), PloS one, 2015, 10 (3): e0121475.

19. Epstein P. Climate change and Human Health, N Engl J Med, 2005, 353: 1433-1436.

20. Shindell D, Kuylenstierna J, Vignati E, van Dingenen R. et al. Simultaneously Mitigating Near-Term Climate Change and Improving Human Health and Food Security, Science, 2012: 335 (6065): 183-189.

21. Reis S, Morris G, Fleming LE et al. Integrating health and environmental impact analysis. Public Health, 2015, 129 (10): 1383-1389.

22. Modeling the Health Risks of Climate Change: Workshop Summary Standing Comitee on Emerging Science for Environmental Health Decisions, Board on Life Sciences, Division on Earth and Life Studies, National Research Council. National Academies Press (US), Washington (DC).

23. Bowles DC, Butler CD, Morisetti N. Climate change, conflict and health. Journal of the Royal Society of Medicine, 2015, 108 (10): 390-395.

24. Zhou XN, Yang GJ, Yang K, Wang XN, Hong QB, Sun LP et al. Potential Impact of Climate Change on Schistosomiasis Transmissions in China. Am J Trop Med Hyg, 2008, 78 (2): 188-194.

25. Hales S, de Wet N, Maindonald J, Woodward A. Potential effect of population and climate changes on global distribution of dengue fever: an empirical model. The Lancet, 2002, 360 (9336): 830-834.

26. Wu X, Lu Y, Zhou S, Chen L, Xu B. Impact of climate change on human infectious diseases: Empirical evidence and human adaptation. Environmental International, 2015, 86: 14-23.

27. Parham PE, Hughes DA. Climate influences on the cost-effectiveness of vector-based interventions against malaria in elimination scenarios. Philosophical Transactions of the Royal Society of London, Series B, Biological Sciences, 2015, 370 (1665).

28. Polley L, Thompson A. Parasites and wildlife in a changing world. Trends in Parasitology, 2015, 31 (4): 123-124.

29. Murray KA, Preston N, Allen T, et al. Global biogeography of human infectious diseases. Proceedings of the National Academy of Sciences of the USA, 2015, 112 (41): 12746-12751. 
30. Medlock JM, Leach SA. Effect of climate change on vector-borne disease risk in the UK. The Lancet. Infectious Diseases, 2015, 15 (6): 721-730.

31. Wang Y, Rao Y, Wu X, Zhao H, Chen J. A method for screening climate change-sensitive infectious diseases. International Journal of Environmental Research and Public Health, 2015, 12 (1): 767-783.

32. Amara AA, Shibl A. Role of Probiotics in health improvement, infection control and disease treatment and management. Saudi Pharmaceutical Journal, 2015, 23 (2): 107-114.

33. Tol. R. Estimates of the Damage Costs of Climate Change. Part 1: Benchmark Estimates. Environmental and Resource Economics, 21 (1): 47-73.

34. Rapport DJ. Costanza R, McMichael AJ. Assessing ecosystem health. Trends in Ecology \&Evolution, 1998, 13 (10): 397-402.

35. Coutts, Hahn M. Green Infrastructure, Ecosystem Services, and Human Health. International Journal of Environmental Research and Public Health, 2015, 12(8): 9768-9798.

36. Ahdoot S, Pacheco SE, Council on environmental health. Global Change and Children's health, Pediatrics, 2015, 136(5): e1468-84.

37. Landrigan PJ, Children's Environmental Health. A Brief History. Academic pediatrics, 2015 Oct 20. pii: S1876-2859(15)00327-7. doi: 10.1016/j.acap.2015.10.002. [Epub ahead of print]

38. Allen JG, MacNaughton P, Laurent JG, Flanigan SS, Eitland ES, Spengler JD. Green Buildings and Health. Current Environmental Health reports, 2015, 2(3): 250-258.

39. Siri JG, Newell B, Proust K, Capon A. Urbanization, Extreme Events, and Health: The case of System Approaches in Mitigation, Management, and Response. Asia-Pacific Journal of Public Health/ Asia-Pacific Academic Consortium for Public health, 2015, Jul 28. pii: 1010539515595694 . [Epub ahead of print]

40. Chadwick AE. Climate Change, Health, and Communication. A Primer. Health Communication, 2015: $1-4$.
Резиме

\section{ВЛИЈАНИЕ НА КЛИМАТСКИТЕ ПРОМЕНИ ВРЗ ЗДРАВЈЕТО}

\section{Нада Поп-Јорданова ${ }^{1}$, Е... Григорова ${ }^{2}$}

${ }^{1}$ Македонска академија на науките и уметностите, Скопје, Р. Македонија 2 Докторанд по јавно здравје, Медицински факултет, Скопје, Р. Македонија

Иако климатските промени претставуваат еден од најголемите здравствени ризици за сите нации, се чини дека медицинските организации во Југоисточна Европа не се премногу загрижени.

Цел на овој труд е да се истакнат најглавните закани за здравјето провоцирани од климатските промени.

Како извор на информации се користени податоци од литературата. Само за 2015 година преку пребарување во PubMed може да се најдат повеќе од 65.000 написи посветени на разни аспекти на влијанието на климатските промени врз хуманото здравје, како и околу 4.500 написи за педијатриската популација. Ова претставува еден ревијален труд за главните здравствени ризици. Особено е обрнато внимание на ризиците врз здравјето на децата.

Во засебни делови се дискутирани термалниот стрес, временските екстремни настани, промените на начинот на пренос на инфективните болести, процената на ризиците, како и мерките за ублажување.

Клучни зборови: климатски промени, здравствени ризици, ревијален труд 